GEOFIZIKA VOL. $38 \quad 2021$

DOI: https://doi.org/10.15233/gfz.2021.38.2

Original scientific paper

(c) (i) (8)

\title{
Earthquakes of 1838 and 1839 in the Slovene Hills (Slovenia) - Međimurje (Croatia) area
}

\author{
Marijan Herak ${ }^{1}$, Davorka Herak ${ }^{1}$, Mladen Živčićc ${ }^{2}$ and Iva Vrkić ${ }^{1}$ \\ ${ }^{1}$ Department of Geophysics, Faculty of Science, University of Zagreb, Zagreb, Croatia \\ ${ }^{2}$ Slovenian Environment Agency, Ljubljana, Slovenia
}

Received 10 November 2020, in final form 20 January 2021

\begin{abstract}
Analyses of available data (newspaper reports, historical and church chronicles, chronical earthquake overviews, travel books, monographies, research papers, etc.) on effects of the earthquakes that shook the greater Ormož area at the Slovenian-Croatian border in the 1838 and 1839 revealed that one of them, recorded in a number of regional and global catalogues, is in fact a fake - the earthquake of 26 August 1838 never happened. This error creeped into various reports and studies, and then into many relevant catalogues, so this event should by systematically erased from the catalogues used to estimate seismicity rates in the neighbourhoods of north-western Croatia, north-eastern Slovenia, and south-western Hungary.

Regarding the earthquake of 31 July 1838, we used important new sources of information that have not been consulted in any previous study. This made inversion of macroseismic parameters more robust. Our estimates of the macroseismic moment magnitude $\left(\mathrm{M}_{\mathrm{wm}}=4.8\right)$ is mostly higher than the values reported in the available catalogues. Reliable information on the effects of the smaller event of 22 March 1839 were found for two localities only, so its epicentre was placed into the town of Ormož where the maximum intensity was observed. Its estimated moment magnitude $\left(\mathrm{M}_{\mathrm{wm}}=4.4\right)$ is close to the median of values found in the six consulted catalogues that listed this event.

The macroseismic epicentre of the 1838 earthquake lies close to the junction of surface traces of the Donat strike-slip fault and the reverse Čakovec fault. Based on their assumed geometry and the location of the macroseismic hypocentre, we give slight preference to the Donat fault as the seismogenic source.
\end{abstract}

Keywords: earthquakes of 1838 and 1839, fake earthquake, Međimurje (Croatia), Slovene Hills (Slovenia)

\section{Introduction}

In the first half of the nineteenth century, in 1838 and 1839, two strongly felt earthquakes occurred in the northern part of Slovenia-Croatia border region. The area lies west of Medimurje (northernmost part of Croatia, Međimurje Hills), east of the Slovene Hills region of Slovenia, south-west of Hungary (Zala County) 
and south-east of Austria (Fig. 1). Seismologically, the area is generally not recognized as an earthquake-prone province. Only a few earthquakes of macroseismic intensity exceeding VII EMS-98 (EMS henceforth, Grünthal et al., 1998) are known to have occurred in the surroundings (e.g. the catalogues by Živčić, 1994; Herak et al., 1996; Stucchi et al., 2013). One such earthquake, which occurred in 1738, was described by Herak et al. (2020). This study is a continuation of the efforts initiated by Herak et al. (2020) to gain better insight into the historical seismicity of the considered region.

The first of the two earthquakes studied here occurred on 31 July 1838 and is known from the literature to have caused damage in several places in Slovenia and the neighbouring Međimurje in Croatia (Mally, 1838; Perrey, 1846; Mallet, 1855; Mallet and Mallet, 1858; Hoernes, 1902; Hoernes, 1903; Réthly, 1952; Kárnik 1971; Shebalin et al., 1974; Ribarič, 1982; Shebalin et al., 1998). This event has been poorly studied so far and there are contradicting data on the time and place of occurrence and the intensity. For the second strongly felt earthquake (but apparently of smaller intensity) that occurred in the same area on 22 March 1839, the data are even scarcer.

General overview of the tectonic setting and of the historical seismicity of the wider region have been presented by Herak et al. (2020) and will not be repeated here, as the two considered areas are close one to another. Let us just reiterate that the seismicity is weak nowadays (Fig. 1a). Since 1908, when the first seismographs with damping devices were installed in Croatia, 24 earthquakes of magnitude 3.5 and above are known to have occurred in the $50 \mathrm{~km}$ radius around the location of the 1838 earthquake, and only four such earthquakes have occurred in the regions of Međimurje and the eastern Slovene Hills. The two largest earthquakes instrumentally recorded as listed in the Croatian Earthquake Catalogue (CEC hereafter; first described by Herak et al., 1996, last updated with data until the end of 2018) occurred on 5 September 1919 at 20:37 $\left(\mathrm{M}_{\mathrm{L}}=4.7\right)$ and on 29 November $1943\left(02: 04, \mathrm{M}_{\mathrm{L}}=4.8\right)$ (Fig. 1b).

However, as already noted by Herak et al. (2020), the locations as well as the intensity and magnitudes of these two earthquakes are uncertain, and various catalogues (e.g. the CEC; Shebalin et al., 1974; Ribarič, 1982; Shebalin et al., 1998; Zsíros, 2000) list them with different epicentres and/or epicentral intensities. The earthquakes of 1738, 1838, and 1839 are - as far as we know - the strongest ones that occurred in this region, and they indicate that damaging earthquakes are not as rare in these parts as it might seem from the catalogue of instrumental seismicity.

Herewith we revisit the case of three events listed in most of the relevant catalogues of this area: the ones of 31 July 1838, 26 August 1838 (fake event, see below!), and 22 March 1839. We hope to provide additional documented data on historical earthquakes, which should result in more consistent and robust record of local seismicity. 

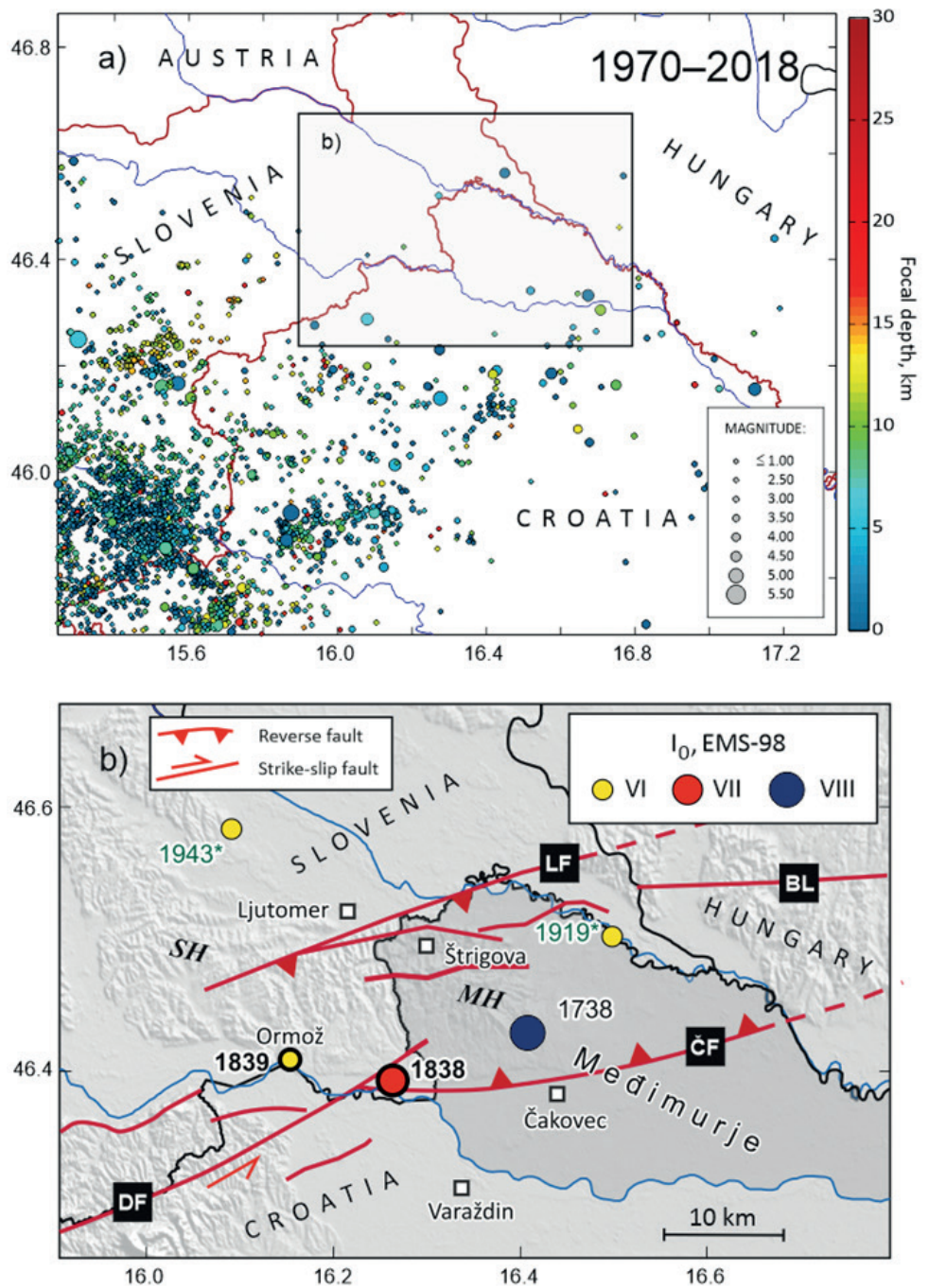

Figure 1. a) Epicentres of instrumentally recorded earthquakes, 1970-2018. Only events located with six or more phases, and with station azimuthal gap less than $180^{\circ}$ are shown. The focal depth is according to the colourbar on the right. The shaded rectangle shows the area depicted in part $b$ ). b) Epicentres of historical earthquakes with epicentral intensity $I_{0} \geq$ VI EMS-98 since the year 1500 (the Croatian Earthquake Catalogue, Herak et al., 1996, updated until the end of 2018). The earthquakes of 1838 and 1839 are shown as circles with thick black outline at the location and with intensity obtained in this study. The fault pattern shown is simplified after Fodor et al. (1999, 2005), Tomljenović and Csontos (2001), Haas et al. (2014), Rajh et al. (2018), Tomljenović (2018), and Tomljenović (personal comm., 2019). BL - Balaton line; ČF - Čakovec fault; DF - Donat fault; LF - Ljutomer fault; $M H$ - Medimurje Hills, $S H$ - Slovene Hills. Modified after Herak et al. (2020).

*According to a preliminary study, the published locations and intensities of the earthquakes of 1919 and 1943 are doubtful. 


\section{The earthquake of 31 July 1838}

\subsection{The sources}

Most of the information was found in contemporary newspapers and journals issued in today's Austria, Croatia, France, Germany, Hungary and Slovakia. Particularly valuable data were retrieved from an article in Steiermärkische Zeitschrift (Mally, 1838) written by a high school professor in Maribor (Slovenia), Georg Mally. At the beginning of September 1838 he visited the parts of Slovenia affected by the earthquake and described damage and other effects. Furthermore, the so-called Dajnko's Chronicles (for more detail see Ožinger, 1988) also mention the effects in the area of today's Ormož (Slovenia) municipality. Peter Dajnko was the pastor at Velika Nedelja, who served there from 1831 to 1870 and wrote the chronicles for the parishes of the Velika Nedelja deanery. We used the quotations from the Chronicles as cited by Rakuša (1886), Kovačič (1910) and Ožinger (1988).

The earthquake was not mentioned in the Slovenian newspapers published at that time. We also consulted documents from the Archives of the Croatian Academy of Sciences and Arts, the Zagreb Archdiocesan Archives, the Metropolitan Library in Zagreb and the National and University Library in Zagreb,

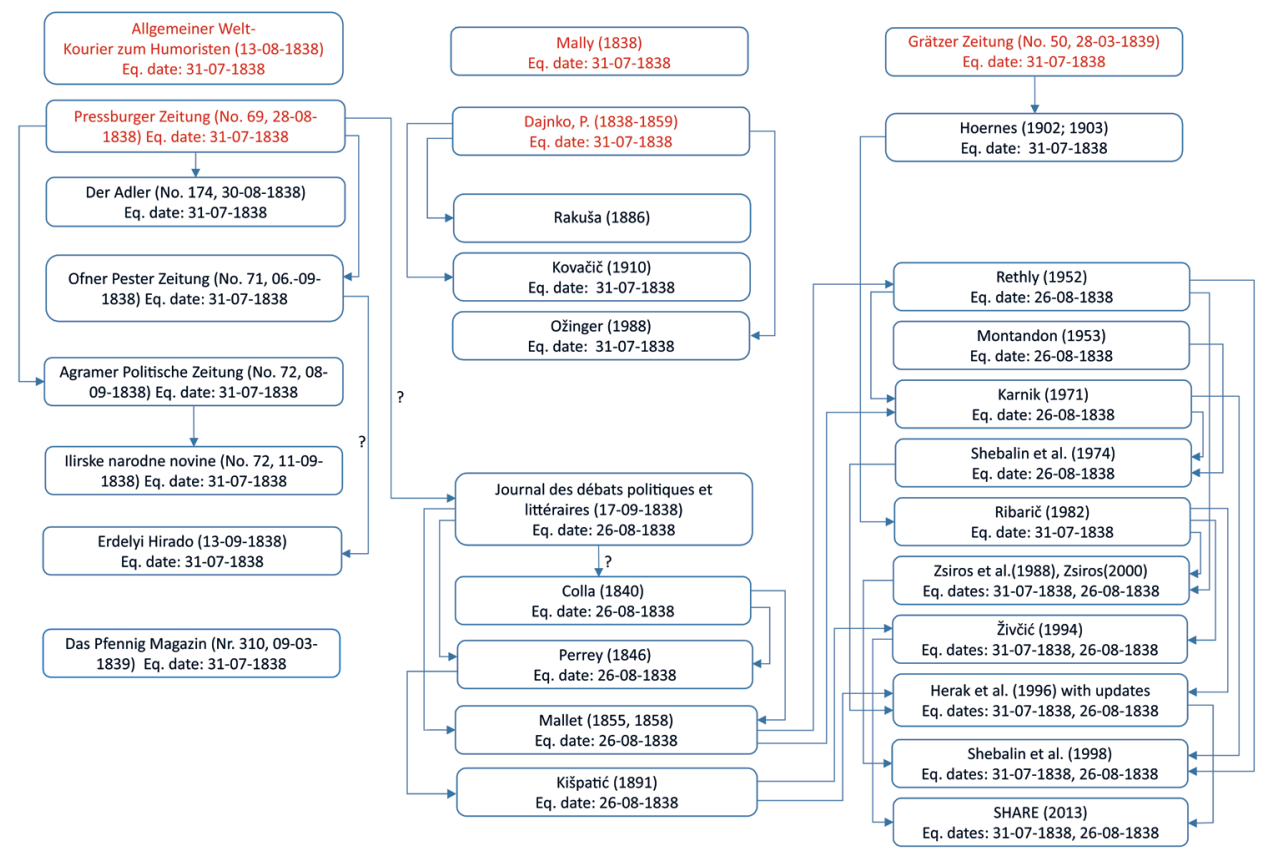

Figure 2. Flowchart of data regarding the earthquake of 31 July 1838 (the primary sources are marked in red). 
as well as the Canonical Visitations for the area of the Archdeaconry of Varaždin, and the Archdiocese of Zagreb (1841). No documents mentioning this earthquake were found.

All subsequent analyses are based on reports contained in the above-mentioned sources (Fig. 2).

\subsection{The date and time}

The primary sources more or less agree on the time of the earthquake (the times vary between 4 p.m. and 4:30 p.m.) but mostly it is reported as 4:15 p.m. local time (15:15 UTC). However, two dates of this event are found in the literature: 31 July 1838 and 26 August 1838. The first date is specified in the contemporary newspapers published after the earthquake - Allgemeiner Welt-Kourier zum Humoristen (No. 33, 13 August 1838), Pressburger Zeitung (No. 69, 28 August 1838), Der Adler (No. 174, 30 August 1838), Ofner Pester Zeitung (No. 71, 6 September 1838), Agramer Politische Zeitung (No. 72, 8 September 1838), Ilirske narodne novine (No. 72, 11 September 1838), Erdelyi Hirado (13 September 1838), Das Pfennig Magazin (No. 310, 9 March 1839), Grätzer Zeitung (Nos. 49, 50; 27 and 28 March 1839) and Allgemeine Zeitung (No. 102, 12 April 1839). The Journal des débats politiques et littéraires (17 September 1838), however, states the date of the earthquake as 26 August 1838, a mistake that will propagate through several earthquake catalogues (Tab. 1).

Based on the articles in the Grätzer Zeitung (27 and 28 March 1839), Hoernes (1902, 1903) wrote about this earthquake and stated that it occurred on 31 July 1838. His information was taken by Ribarič (1982) who was then cited by a

Table 1. The 1838 earthquake parameters as given in various catalogues and after this study.

\begin{tabular}{|c|c|c|c|c|c|c|c|}
\hline & Author(s) & Date & Lat. ${ }^{\circ} \mathrm{N}$ & Lon. ${ }^{\circ} \mathrm{E}$ & $\begin{array}{l}\text { Depth } \\
(\mathrm{km})\end{array}$ & $\begin{array}{l}\text { Epicentral } \\
\text { intensity, } I_{0}\end{array}$ & M \\
\hline 1 & Réthly (1952) & 26 Aug. 1838 & 46.5 & 16.28 & 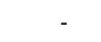 & - & - \\
\hline 2 & Kárnik (1971) & 26 Aug. 1838 & 46.3 & 16.3 & - & VII MSK & - \\
\hline 3 & Shebalin et al. (1974) & 26 Aug. 1838 & 46.3 & 16.3 & - & VII MSK & - \\
\hline 4 & Ribarič (1982) & 31 July 1838 & 46.417 & 16.183 & 7.3 & VI MSK & 3.83 \\
\hline 5 & Zsíros et al. (1988) & $\begin{array}{l}31 \text { July } 1838 \\
26 \text { Aug. } 1838\end{array}$ & $\begin{array}{l}46.42 \\
46.50\end{array}$ & $\begin{array}{l}16.18 \\
16.28\end{array}$ & $\begin{array}{l}7 \\
-\end{array}$ & $\begin{array}{l}\text { VI MSK } \\
\text { V MSK }\end{array}$ & $\begin{array}{l}3.8 \\
3.8\end{array}$ \\
\hline 6 & CEC (Herak et al., 1996) & $\begin{array}{l}31 \text { July } 1838 \\
26 \text { Aug. } 1838\end{array}$ & $\begin{array}{l}46.417 \\
46.45\end{array}$ & $\begin{array}{l}16.183 \\
16.300\end{array}$ & $\begin{array}{r}7.3 \\
-\end{array}$ & $\begin{array}{l}\text { VI MSK } \\
\text { VII MSK }\end{array}$ & $\begin{array}{l}4.07 \\
5.30\end{array}$ \\
\hline 7 & Shebalin et al. (1998) & $\begin{array}{l}31 \text { July } 1838 \\
26 \text { Aug. } 1838\end{array}$ & $\begin{array}{l}46.42 \\
46.40\end{array}$ & $\begin{array}{l}16.18 \\
16.90\end{array}$ & $\begin{array}{l}10 \\
18\end{array}$ & $\begin{array}{l}\text { V MSK } \\
\text { VII MSK }\end{array}$ & $\begin{array}{l}3.6 \\
5.7\end{array}$ \\
\hline 8 & Zsíros (2000) & $\begin{array}{l}31 \text { July } 1838 \\
26 \text { Aug. } 1838\end{array}$ & $\begin{array}{l}46.50 \\
46.50\end{array}$ & $\begin{array}{l}16.28 \\
16.30\end{array}$ & - & $\begin{array}{l}\text { VI EMS } \\
\text { V EMS }\end{array}$ & $\begin{array}{l}4.2 \\
3.5\end{array}$ \\
\hline 9 & SHARE (2013) & $\begin{array}{l}31 \text { July } 1838 \\
26 \text { Aug. } 1838 \\
\end{array}$ & $\begin{array}{l}46.42 \\
46.50\end{array}$ & $\begin{array}{l}16.18 \\
16.28 \\
\end{array}$ & $\begin{array}{l}7 \\
-\end{array}$ & - & $\begin{array}{l}4.46 \\
3.80 \\
\end{array}$ \\
\hline 10 & This study & 31 July 1838 & 46.39 & 16.27 & 5 & 7.2 EMS & $\mathrm{M}_{\mathrm{wm}} 4.80$ \\
\hline
\end{tabular}


number of authors (see Fig. 2). The date of 26 August was published by Colla (1840), Perrey (1846), Mallet (1854), Mallet and Mallet (1858), Kišpatić (1891) and Réthly (1952).

Colla (1840) does not cite his source (we assume it was the Journal des débats politiques et littéraires, 17 September 1838). Perrey (1846), Mallet (1854), and Mallet and Mallet (1858) cite that issue of the Journal, as well as the work of Colla (1840). Kišpatić (1891) retrieved the information from Perrey (1846), but wrote incorrectly that the earthquake caused much damage in Hungary (Barč and Kaniža, instead of Raczkaniza (Razkrižje) in Slovenia), and Varaždin (Croatia). Kárnik (1971) took the date and epicentre from Réthly (1952), while Shebalin et al. (1974), citing both Réthly (1952) and Kárnik (1971), published the wrong epicentre and the wrong date (subsequently taken over by e.g. Herak et al., 1996). Hoernes (1902) wrote that Perrey (1846) and Kišpatić (1891, who cited only Perrey, 1846) mentioned the earthquake of 26 August 1838, but also that he could not find any credible confirmation of this.

Where did this date confusion come from? As far as we could find out, the date of 26 August appeared first in Journal des débats politiques et littéraires on 17 September 1838. The text begins with: On écrit de Pressbourg (Hongrie), le 30 Aout: "Le 26 de ce mois, une partie du comitat de Zalander, en Hongrie, a éprouvé un tremblement de terre très violent, ..." (It is reported from Pressburg (Hungary) on 30 August: "On the 26th of this month, part of the Zala county, in Hungary, experienced a very violent earthquake, ...") (Pressburg is today's Bratislava, Slovakia). The text that follows is the translation and interpretation of the text that originally appeared first in the Pressburger Zeitung on 28 August 1838, with one exception - in the original report the date provided was 31 July. The original report from Pressburger Zeitung was subsequently taken over and published by the Austrian, Croatian, German and Hungarian papers (see Fig. 2). Among those, Ilirske Narodne Novine published it in Croatian translation on 11 September 1838. Figure 3 shows the article in question. All their notes start with an introductory line about the origin and (sometimes) the date of the news. This one starts with "Iz Medjimurja." ("From Međimurje."). The next note starts with "Iz Pešte 26. Kolovoza (Aug.)" (From Pest on 26 August). 'Pest' is now a part of Budapest, Hungary, and was a separate city at the time of the earthquake. It is possible that the editors of the Journal (or the reporter from Pressburg) had, among others, also a copy of Ilirske narodne novine, and mistook the introductory line of the next article for the concluding line of the previous article, and interpreted it as the actual date of the earthquake!

The 'earthquake' with the date of 26 August 1838 and the epicentre near Varaždin (Croatia) is included in the Catalogue of Earthquakes for the Balkan Region (Shebalin et al., 1974), but it is not found in the atlas of 493 macroseismic maps of severe earthquakes in the Balkans (Shebalin, 1974). As such it is taken over in the Earthquake Catalogue for Central and Southeastern Europe 342 BC-1990 AD (Shebalin et al., 1998), as well as into the Seismic Hazard Harmo- 


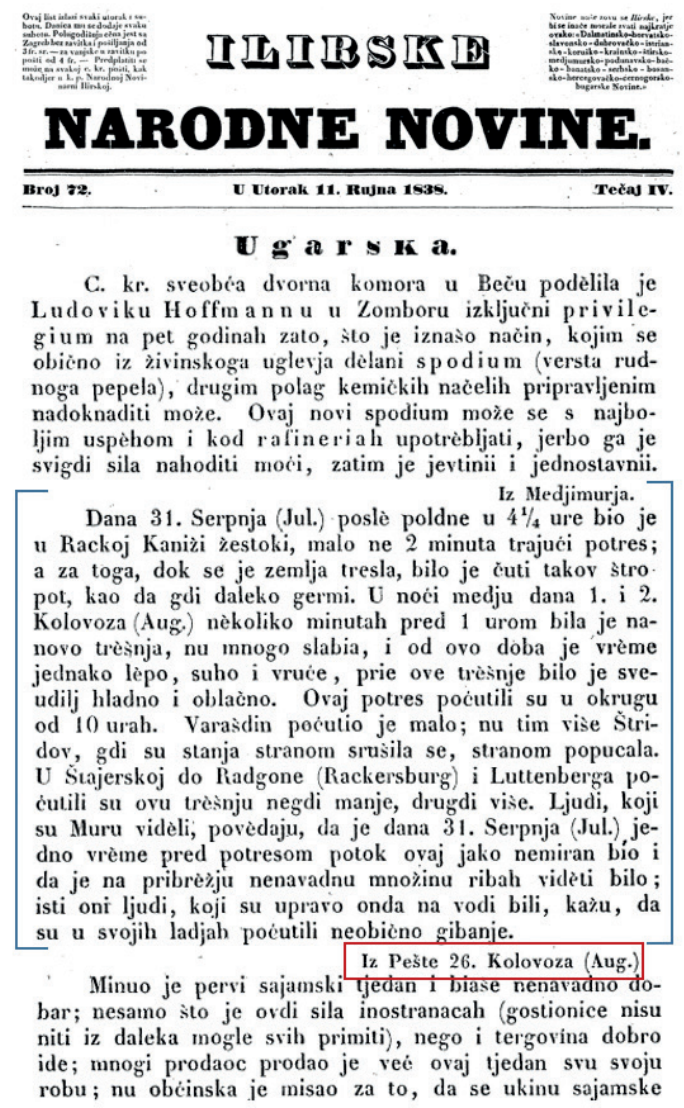

Figure 3. A possible source of confusion about the date of the earthquake. Article in Ilirske narodne novine (11 September 1838) with information about the earthquake (blue brackets). The date of the next news item, 26 August, is shown within the red box.

nization in Europe (SHARE) European Earthquake Catalogue 1000-1899 (Stucchi et al., 2013). This fake event was also included in the CEC (Herak et al., 1996), the Hungarian earthquake catalogues by Zsíros et al. (1988) and Zsíros (2000) with an underestimated intensity and with an epicentre in Štrigova (Croatia) and Međimurje region (Muraköz), respectively (Fig. 2). Table 1 tabulates the parameters of both the 31 July 1838 earthquake and the 26 August fake earthquake as given in various catalogues. As can be seen (see also Fig. 4), the result of this game of "Chinese whispers" is that today, instead of one strong earthquake on 31 July 1838, some catalogues list the wrong date and/or place, and many catalogues even contain both earthquakes in the wider border area of Croatia and Slovenia. The range of intensities reported is V to VII-VIII (various macroseismic scales). 


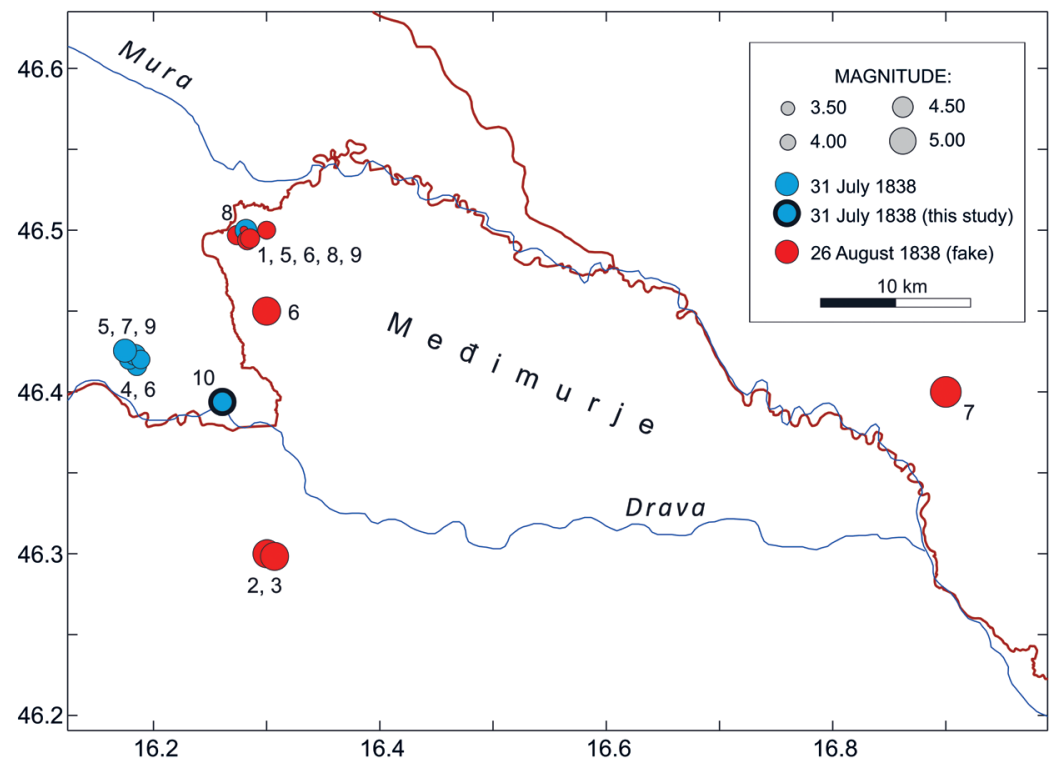

Figure 4. Locations of the earthquake of 31 July 1838 (and the fake event of 26 August 1838) according to catalogues listed in Tab. 1. Number(s) next to the circles indicate the corresponding entry in Tab. 1. Some epicentres were slightly shifted to prevent overlap.

\subsection{Earthquake effects and damage to individual sites / buildings}

In order to assign the macroseismic intensity to a particular site, it is necessary to understand how a typical house was built at the time of the earthquake. Vogrinčič (2011) states that the Goričko region (north of the Mura, between Austria and Hungary, i.e. the Prekmurje region) is characterized by the so-called Pannonian house, which may be divided into four subtypes: I) loam house; II) house made of wooden planks lined with mixture of loam and lime (cimprane hiše); III) wooden house (ancillary buildings) and IV) the masonry house (made of baked bricks). They were mostly low, had small windows and straw-covered roofs. Cimprane hiše were also traditionally built in the Slovene Hills region (e.g. Gomboc, 2013; Sedej, 1988/90). These types of construction can be seen in Fig. 5 , and are classified as vulnerability class A-B (subtypes I and IV), or D (subtypes II and III) according to the EMS scale.

In the following, we present evidence of effects and/or damage related to the earthquake of 31 July 1838. We will refer to localities with their contemporary names, giving the names as cited in the sources in the parentheses.

Zavrč (Slovenia; Ger. Sauritsch): Mally (1838) wrote that clear cracks appeared on the Church of Our Lady (Slo. Sv. Marija Vnebovzeta; Ger. Frauenkirche) (masonry building). The wooden roof cornice and statues of angels fell from the altar. At the Deanery in Zavrč, plaster fell between the wall and the 

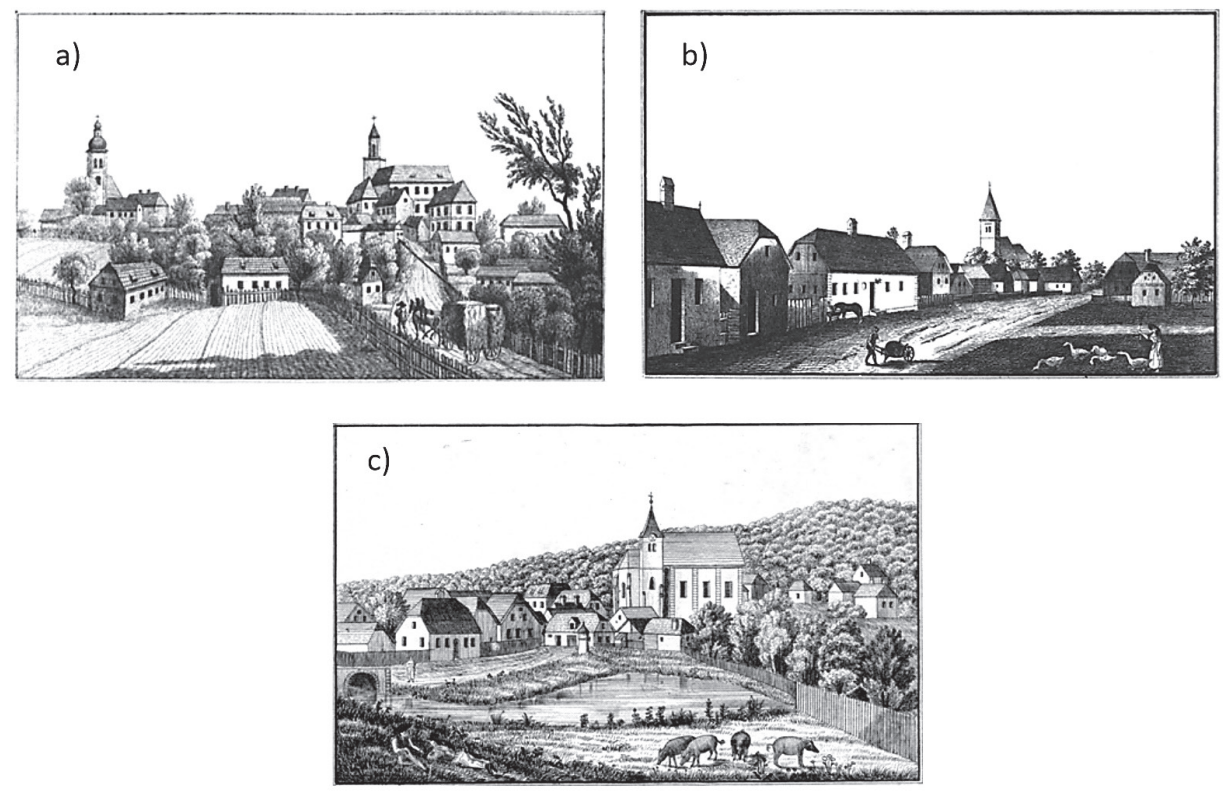

Figure 5. Lithographs of: a) Ormož in 1825; b) Središče ob Dravi in 1830; c) Ljutomer in 1830 (Kaiser, 1825-1833).

ceiling in one of the rooms. Damage ("starke Risse") to buildings in Zavrč is also mentioned in Grätzer Zeitung in its issue of 27 March 1839, although, most probably wrongly, assigned to the event of 2 August 1838 (1 August 1838 after UTC, see below).

Ormož (Slovenia; Ger. Friedau): according to Mally (1838) something happened in every house. In the article about another earthquake (of 22 March 1839), Grätzer Zeitung (28 March 1839) mentioned that the same phenomenon occurred on 31 July 1838 at 4:30 in the afternoon and that no one, not even the eldest people, could remember such violent earthquakes. While describing effects in Središče ob Dravi (see below) Ožinger (1988, citing Dajnko's Chronicles) wrote also that "The earthquake was probably the strongest in Ormož, where severe cracks appeared in the walls.".

Church of St. Miklavž in the Ljutomer hills (Slovenia; Ger. Pfarrkirche St. Nikolai im Luttenberger-Gebirge): The parish church was so shaken that it had to be examined for safety. The earthquake was felt in the open (Mally, 1838), and was accompanied with a thunderlike sound.

The earthquake was also felt in the Ptuj Field (Slovenia, Ptujsko polje; Ger. Pettauerfelde), especially around Dornava (Ger. Dornau) where it left traces on many buildings. However, it seems that it was the most violent in the areas of Zavrč, Središče ob Dravi and Ljutomer Hills (Mally, 1838). 
In the area of St. Areh on Pohorje (Slovenia; Ger. Bachergebirge bei St. Heinrich) and the glass factory in Limbuš (Slovenia; Ger. Glasfabrik zu Oberlembach) the earthquake was felt much more strongly than in Maribor. It appears to have been stronger on rocky grounds than in the Drava valley and in the Slovene Hills (Ger. Windische Bühel) (Mally, 1838).

Razkrižje (Slovenia; Hun. Ráczkanizsa): The Pressburger Zeitung of $28 \mathrm{Au}$ gust 1838 reports about a major (important) earthquake lasting for nearly 2 minutes (?!) accompanied by a sound resembling a distant thunder.

Središče ob Dravi (Slovenia; Ger. Markt Polsterau, Polstrau): According to Mally (1838) the shaking was here even stronger than in Ormož, the school building was particularly damaged. Ožinger (1988) also wrote about the earthquake in Središče as described in Dajnko's Chronicles: "On 31 July 1838 around $4.30 \mathrm{pm}$, a strong earthquake was felt in Središče and its surroundings, which caused considerable damage to houses, the church, the parish house, and the school, and which strongly upset people". Kovačič (1910) cites the Dajnko's Chronicles (1840) where this quake in Središče is extensively described: "In the year of 1838 on the afternoon of July 31, at half past four, there was earthquake in Središč so strong that no one in the whole neighbourhood remembered a similar one. The walls of the church, the rectorate and the school got large cracks. This earthquake had a strange effect on the animals. The poultry fled with loud cries to the meadows, to the open away from the houses, and trees swayed as if the wind were blowing, although the air was completely still. The dogs howled, the cats meowed and hid away ... People outdoors could feel the ground shaking under their feet, and also heard noise and rustling. To the pastor Salamun and the teacher Karničnik, who were standing just in front of the school and talking, it seemed that the school leaned so much, they thought it was about to fall on them. Water splashed from puddles and streams; boatmen and millers noticed on the Drava that the waves had risen and the water along the banks rose nearly 3 feet. This earthquake was felt between Velika Kaniža and Celje, Slovenj Gradec, Maribor, Arnovž, Vildon and Sobotišče in Hungary, i.e. between the rivers Sava, Drava, Mura and Rab."

In Ljutomer (Slovenia; Ger. Markt Luttenberg) the ground staggered so violently that the inhabitants rushed out of the houses with a scream of fear. The houses on stony ground apparently suffered more (Mally, 1838).

Maribor County (Slovenia; Ger. Kreisstadt Marburg): Mally (1838) wrote: „On 31 July 1838, at half past four in the evening, there was an earthquake in some parts of the Marburg (Maribor) District, which may not have been insignificant, since, according to the testimony of many witnesses, the tables and chairs were shaken in some houses. However, as none of this was noticed in many streets in the city, many people considered it an illusion, which is why not a single report appeared in the Grätzer Zeitung. Shortly afterwards, some customs offices on the Croatian border sent reports to the Royal and Imperial Cameral administration in Maribor of noticeable damage to their offices by an earthquake, which coin- 
cided in time with the one observed in Maribor so precisely that it could be concluded that the earthquake occurred at the same time, but in the eastern areas of Maribor and Celje Districts as well as in neighbouring Croatia and Hungary, it was perceived much strongly and more evenly."

For the town of Velika Nedelja (Slovenia; Ger. Gross Sonntag) Rakuša (1886) cites the Parish chronicles (Dajnko's Chronicles): "In 1838 there was such a strong earthquake that the Drava spilled and cats and dogs were hiding in fear".

Rogaška Slatina (Slovenia; Ger. Rohitsch Sauerbrunn): No damage, two strong jerks and a later swing (Allgemeiner Welt-Kourier zum Humoristen, 13 August 1838).

Lendava (Slovenia; Hun. Alsólendva): At the web-site Lendava na spletu (2020) one reads: "In 1838 Lendava was struck by several earthquakes and a large fire." This citation is possibly a misinterpretation of the note from the monography of Lendava (Šimonka and Bence, 2005) which reads: „The settlement was struck by several earthquakes and fires, the largest of which in 1838." As a large fire occurred around Christmas of 1838 (Gornjec et al., 1981), the cited year probably refers to that event and not to the earthquake.

Pressburger Zeitung (28 August 1838) reports that the earthquake was felt as far as Ljutomer (Slovenia; Ger. Luttenberg) and Radgona (Slovenia; Ger. Rackersburg).

Štrigova (Croatia; Ger. Stridau) and Varaždin (Croatia, Ger. Warasdin) - From the report in Pressburger Zeitung (28 August 1838): "Little was felt of it in Warasdin, but the more so in Stridau, where buildings partly collapsed and partly cracked." This was taken over by many newspapers [e.g. the Agramer Zeitung (8 September 1838), Ilirske narodne novine (11 September 1838), Journal des débats politiques et littéraires (17 September 1838)] and Perrey (1846, who was then cited by Réthly, 1952), sometimes losing some of the meaning in translation and interpretation.

Komárom County (Slovakia/Hungary, It: Comitato di Komorn), and $\mathbf{N y}$ itra County (Slovakia, It: Comitato di Neutra) - The two neighbouring counties of the former Hungarian kingdom are more than $200 \mathrm{~km}$ away from the epicentre. Colla (1840) noted: "A few shocks were also felt in some places of the Neutra and Komorn counties, but they were very short and caused no damage." The source for this statement was not given. This region is seismically active and an earthquake is known to have occurred near Komárom on 22 July 1838 (Fehér Ipoly, 1874). Colla most probably referred to that event and its aftershocks.

Mura river - "Credible eyewitnesses state that on 31 July, some time before the shock, the Mura river was extremely restless and there were unusually many fish on the banks; even people who were on the water at that time assured that they had experienced an unusual movement in their ships." (Pressburger Zeitung, 28 August 1838). 
Table 2. Localities, assigned intensity, and a subjectively determined weight (W) reflecting the consistency and amount of data used in inversion of macroseimic parameters for the earthquake of 31 July 1838.

\begin{tabular}{lcccc}
\hline Locality & Lat. ${ }^{\circ} \mathrm{N}$ & Lon. $^{\circ} \mathrm{E}$ & I $_{\text {obs }}(\mathrm{EMS})$ & $W$ \\
\hline Središče ob Dravi & 46.396 & 16.270 & VII & 3 \\
Štrigova & 46.499 & 16.283 & VII & 1 \\
Ormož & 46.409 & 16.151 & VI-VII & 1 \\
Miklavž pri Ormožu & 46.458 & 16.214 & VI & 2 \\
Zavrč & 46.386 & 16.047 & VI & 2 \\
Dornava & 46.445 & 15.989 & VI & 1 \\
Velika Nedelja & 46.420 & 16.110 & V-VI & 1 \\
Razkrižje & 46.525 & 16.276 & V & 1 \\
Rogaška Slatina & 46.233 & 15.638 & IV-V & 1 \\
Maribor & 46.554 & 15.646 & IV-V & 1 \\
Limbuš & 46.554 & 15.582 & F & 0 \\
Ljutomer & 46.519 & 16.198 & F & 0 \\
Pohorje Sv. Areh & 46.495 & 15.509 & F & 0 \\
Radgona & 46.677 & 16.000 & F & 0 \\
Varaždin & 46.306 & 16.337 & F & 0 \\
\hline
\end{tabular}

Based on data as concisely described above we estimated the intensity $\left(I_{o b s}\right)$ for each of the localities where the earthquake was experienced, and present them in Tab. 2 and in Fig. 6. In the table we also add a simple subjective relative weight $(W)$ that was used in inverting the observed intensities (see also Herak et al., 2020), which reflects the consistency and amount of available data, and thus our confidence in the assigned intensity value.

\subsection{Inversion of macroseismic parameters}

Observed intensities $\left(I_{o b s}\right)$ were inverted for the epicentre, depth, and epicentral intensity of the 31 July 1838 earthquake using the program MEEP v.2.0 by Musson (2009) modified as described in detail by Herak et al. (2018, 2020). Reports indicating only that shaking was felt ('F') were not used. Of the four inversion algorithms built into MEEP, we used the two found to be the most stable ones for our dataset: the MEEP method, and the centroid method (very similar to the Boxer code by Gasperini et al., 1999). All options regarding bootstrap procedures, handling in-between integer intensity data points, data weighting, and computing the confidence regions remain the same as used by Herak et al. (2020).

The soil in the Slovenian Hills and the Medimurje Hills regions mostly consist of marls, clays, sandy clays, sands and alluvial deposits (Mioč and Marković, 1998). As such, we assumed that it falls into a broad category of average soil. Therefore, the intensity data points $I_{\text {obs }}$ were taken in the inversion of macroseismic parameters as estimated in Table 2, i.e. with no intensity adjustments. 
The final representative location was defined as the barycentre (mean) of 2000 bootstrap solutions (with replacements), 1000 for each method used. Standard errors of the hypocentral coordinates are represented by the extent of the $68 \%$ elliptical confidence region (Fig. 6). The inversion yielded the following coordinates of the macroseismic epicentre $(\varphi, \lambda)$, focal depth $(h)$ and the epicentral intensity $\left(I_{0}\right)$ :

$$
\begin{gathered}
\varphi=46.39^{\circ} \mathrm{N} \pm 7 \mathrm{~km}, \lambda=16.27^{\circ} \mathrm{E} \pm 6 \mathrm{~km}, \mathrm{~h}=5 \pm 2 \mathrm{~km} \\
I_{0}=7.2 \operatorname{EMS}(\sigma=0.47 \mathrm{EMS}) .
\end{gathered}
$$

This solution was obtained assuming the values of the isoseismal parameter $(k=2.6)$ and of the regional attenuation coefficient $\left(\alpha=0.005 \mathrm{~km}^{-1}\right)$ in Kövesligethy's (1906) formula

$$
I=I_{0}-k \log _{10}(R / h)-k a \mu(R-h)
$$

that minimized the overall standard error $\sigma$. Here $I$ is the intensity at the hypocentral distance $R$, and $\mu=\log _{10}(e)=0.4343$.

The confidence ellipses presented in Fig. 6 are centred at the epicentre and comprise $68 \%$ and $95 \%$ of all 2000 bootstrap solutions. They are defined as described in Herak et al. (2020).

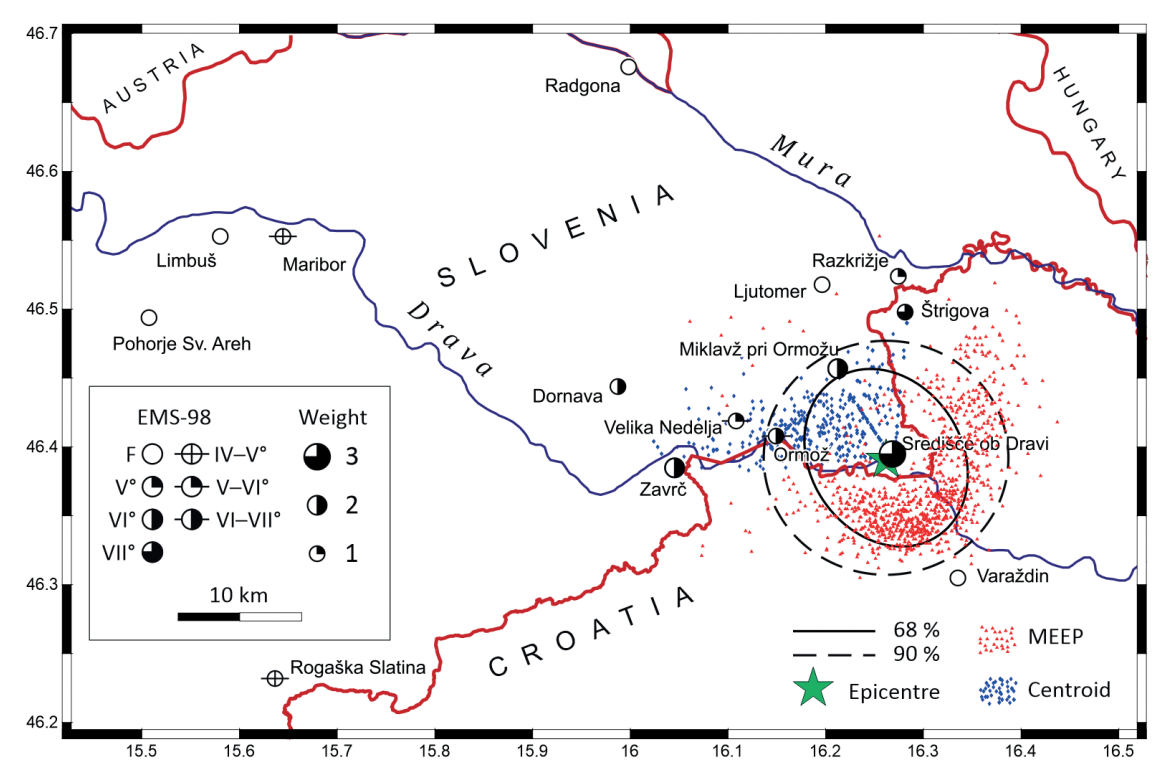

Figure 6. Intensity (EMS) map for the earthquake of 31 July 1838. The small red and blue symbols are the 2000 bootstrap solutions using the MEEP and Centroid methods, respectively. The green star is the barycentre of all bootstrap solutions, i.e. the macroseismic epicentre. The full and dashed ellipses denote the $68 \%$ and $90 \%$ confidence regions, respectively. 
The local macroseismic magnitude was estimated from regressions linking the local magnitude $\left(\mathrm{M}_{\mathrm{L}}\right)$, epicentral intensity $\left(I_{0}\right.$, EMS), and focal depth $(h)$ in Croatia, by Herak (1995):

$$
\mathrm{M}_{\mathrm{L}}=0.721 I_{0}+1.283 \log _{10}(h)-1.13,
$$

and for Slovenia, using the magnitude $\mathrm{M}_{\mathrm{LH}}$ (Kárnik, 1969), by Živčić (1994):

$$
\mathrm{M}_{\mathrm{LH}}=0.494 I_{0}+1.27 \log _{10}(h)+0.09,
$$

which yield $\mathrm{M}_{\mathrm{L}}=5.0$ and $\mathrm{M}_{\mathrm{LH}}=4.5$, respectively. If the two magnitudes are converted to the moment magnitude $\left(\mathrm{M}_{\mathrm{w}}\right)$ using relations proposed for the Croatian catalogue by Herak (2020):

$$
\mathrm{M}_{\mathrm{w}}=-0.106+1.002 \mathrm{M}_{\mathrm{L}}
$$

and the one used in Slovenia (Grünthal et al., 2009),

$$
\mathrm{M}_{\mathrm{w}}=0.65+0.906 \mathrm{M}_{\mathrm{LH}}
$$

we obtain $\mathrm{M}_{\mathrm{w}}=4.9$ and $\mathrm{M}_{\mathrm{w}}=4.7$, respectively. As a representative macroseismic moment magnitude we thus propose to use their average, $\mathrm{M}_{\mathrm{wm}}=4.8$ with index ' $\mathrm{m}$ ' denoting the macroseismically estimated $\mathrm{M}_{\mathrm{w}}$.

The macroseismic epicentre is located about $9 \mathrm{~km}$ to the east of Ormož, at the place where surface traces of the strike-slip Donat fault and the reverse Cakovec fault meet (Fig. 1b). It is reasonable to assume that Donat fault is steeper than Cakovec fault, so it could be argued that due to the vicinity of the source to the surface trace of both faults, the Donat fault is more likely to be the causative one. However, given the uncertainties of the location of the focus and of the faults' position and geometry, neither of the two faults can be excluded as the source.

\subsection{Aftershocks}

In the night between the $1^{\text {st }}$ and the $2^{\text {nd }}$ of August 1838, just a few minutes before 1 am CET (or just before midnight of 1 August according to UTC), an aftershock of the 31 July event was felt in the same area. The first report was the one by the Pressburger Zeitung 27 days later, which was then repeated by Der Adler (30 August 1838). The newspapers assume the same location as for the mainshock, and report that the quake was felt, with no additional detail. The catalogue by Zsíros (2000) lists also the events of 2 August 1838 near Zavrč (probably 1 August, see above), 26 August 1838 near $\breve{S}$ trigova $\left(\mathrm{M}=3.5, I_{0}=\mathrm{V}\right.$ EMS, fake event, see above!), and 1 September 1838 close to Razkrižje. Colla (1840) also reports that aftershocks followed one another so rapidly that they could not be counted.

\section{Earthquake of 22 March 1839}

A moderate earthquake occurred in the Ormož area on 22 March 1839 (about 5:15 CET), almost eight months after the event of 31 July 1838. 


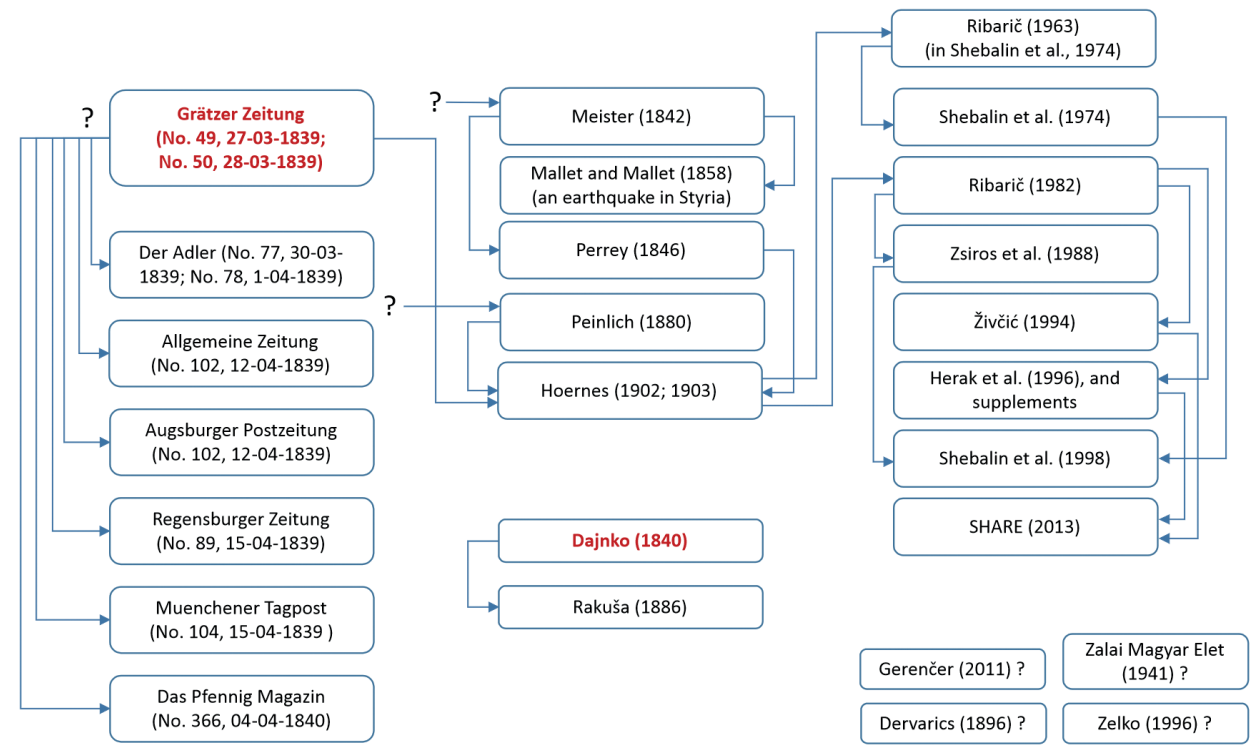

Figure 7. Data flowchart related to the earthquake of 22 March 1839.

\subsection{Data sources for the 1839 earthquake}

The main source of information for this earthquake is the Grätzer Zeitung (issues of 27 and 28 March 1839) (Fig. 7).

In addition to Grätzer Zeitung, other newspapers also wrote about the earthquake: Der Adler (1 April 1839), Allgemeine Zeitung (12 April 1839), Augsburger Postzeitung (12 April 1839), Münchener Tagpost (15 April 1839), Regensburg-

Table 3. 22 March 1839 earthquake parameters as given in various catalogues and after this study.

\begin{tabular}{lccccc}
\hline Authors & Lat. ${ }^{\circ} \mathrm{N}$ & Lon. ${ }^{\circ} \mathrm{E}$ & $\begin{array}{c}\text { Depth } \\
(\mathrm{km})\end{array}$ & $\begin{array}{c}\text { Epicentral intensity } \\
I_{0}\end{array}$ & $\mathrm{M}$ \\
\hline Réthly (1952) & & \multicolumn{5}{c}{ missing } \\
Kárnik (1971) & & \multicolumn{5}{c}{ missing } \\
Kissing & \\
Kišpatić (1891) & & & \multicolumn{5}{c}{ VI-VII MSK } & - \\
Shebalin et al. (1974) & 46.4 & 16.1 & - & VI-VII MSK & 4.17 \\
Ribarič (1982) & 46.400 & 16.117 & 7.5 & VI-VII MSK & 4.2 \\
Zsíros et al. (1988) & 46.40 & 16.12 & 7 & VI-VII MCS & 4.43 \\
CEC (Herak et al., 1996) & 46.40 & 16.117 & 7.5 & VI-VII MSK & 4.5 \\
Shebalin et al. (1998) & 46.40 & 16.1 & 10 & VI-VII EMS & 4.6 \\
Zsíros (2000) & 46.40 & 16.12 & - & - & 4.79 \\
SHARE (2013) & 46.40 & 16.12 & 7.5 & $\mathbf{6 . 5}$ EMS & $\mathbf{M}_{\mathbf{w m}} \mathbf{4 . 4}$ \\
\hline This study & $\mathbf{4 6 . 4 1}$ & $\mathbf{1 6 . 1 5}$ & $\mathbf{5}$ &
\end{tabular}


er Zeitung (15 June 1839), Das Pfennig Magazin (4 June 1840), and possibly Zalai Magyar Élet (14 June 1941; without the actual date of the earthquake). As those newspapers bring no additional data, it is reasonable to assume that they all just used the articles from the Grätzer Zeitung.

According to Hoernes (1902, 1903), Peinlich (1880) calls the year 1839 one of the earthquake years in Styria and mentions the earthquake of 22 March 1839, but with no detail of how the earthquake was felt. Hoernes $(1902,1903)$ himself only summarized the reports from the two articles in Grätzer Zeitung. Neither Colla (1841) nor Kišpatić (1891) mention this earthquake.

The earthquake parameters given in various catalogues are summarized in Tab. 3.

\subsection{Reported effects}

As mentioned above, essentially all that is known about the 22 March 1839 event is reported by the Grätzer Zeitung newspapers (see Fig. 7).

The article of 27 March is written according to a letter of an eyewitness from Zavrč (Slovenia; Ger. Sauritsch) dated 23 March, who reported that a considerable earthquake was felt there, accompanied by a distant thunderlike sound. The vibrations were so strong that the writer of the letter could hardly keep his balance. Besides this, only a clink of the windowpanes and other glassware was heard.

Another eyewitness account was published the next day (24 March), and it came from Ormoż (Slovenia, Ger. Friedau). Although the earthquake lasted only for few seconds, it induced "no small horror" amongst the inhabitants, and is described as 'violent'. The people "...who were mostly in bed, were startled and ran out of their houses in fear onto the alley. The bricks fell from the roofs, the windows and glasses clinked in the cupboards, devices and pictures in frames on the walls began to swing and pendulum clocks stopped. Walls cracked or the mortar fell."

Rakuša (1886), citing the Parish Chronicle (Dajnko, 1840), mentioned that on 22 March 1839 there was an earthquake in Velika Nedelja.

In the report from Zavrč (see above), there is also a vague assertion that "In Croatia, where the shock seemed to have come from, as last year, it will have been much more violent." The source for this statement is unknown (perhaps only an assumption?), as we could not find any source mentioning effects of this earthquake on Croatian soil.

Besides Zavrč, Ormož, and Velika Nedelja the only locality briefly mentioned in the documents we had on disposal is Lendava. Gerenčer (2011) wrote in her diploma thesis: "In 1839 Lendava was also hit by a large earthquake in which many stone houses were affected", but we could not find the source for this information. The same holds for Zelko (1996) who wrote that in Lendava there was great earthquake in 1839 that caused cracks in many stone houses' walls but also cited no sources. Zalai Magyar Élet (1941) also brought a single sentence 
Table 4. Localities and assigned intensity used in inversion of macroseimic parameters for the earthquake of 22 March 1839. Parentheses indicate uncertain estimate.

\begin{tabular}{lccc}
\hline Locality & Lat. ${ }^{\circ} \mathrm{N}$ & Lon. ${ }^{\circ} \mathrm{E}$ & $I_{\text {obs }}(\mathrm{EMS})$ \\
Ormož & 46.409 & 16.151 & VI-VII \\
Zavrč & 46.386 & 16.047 & (V-VI) \\
Velika Nedelja & 46.620 & 16.110 & Felt \\
\hline
\end{tabular}

about a strong earthquake in Lendava (Hun. Alsolendva) in 1839, again with no source or date indicated. Similarly, Dervarics (1896) stated that in the autumn (!) of 1839 there was a great earthquake in Lendava with no further info. As Hoernes $(1902,1903)$ wrote about the earthquake on 17 October 1839 that was strongly felt in Graz, Bruck, and Hieflau it is possible that it was also felt in Lendava, and that all of the notes above refer to this autumn event, and not to the one of 22 March. We are therefore left with only three localities - Zavrč, Ormož and Velika Nedelja (Tab. 4). The intensity estimated for Zavrč is based on one account only, so we consider it uncertain. For Ormož description is more detailed reporting effects on the community, so we regard it as more reliable.

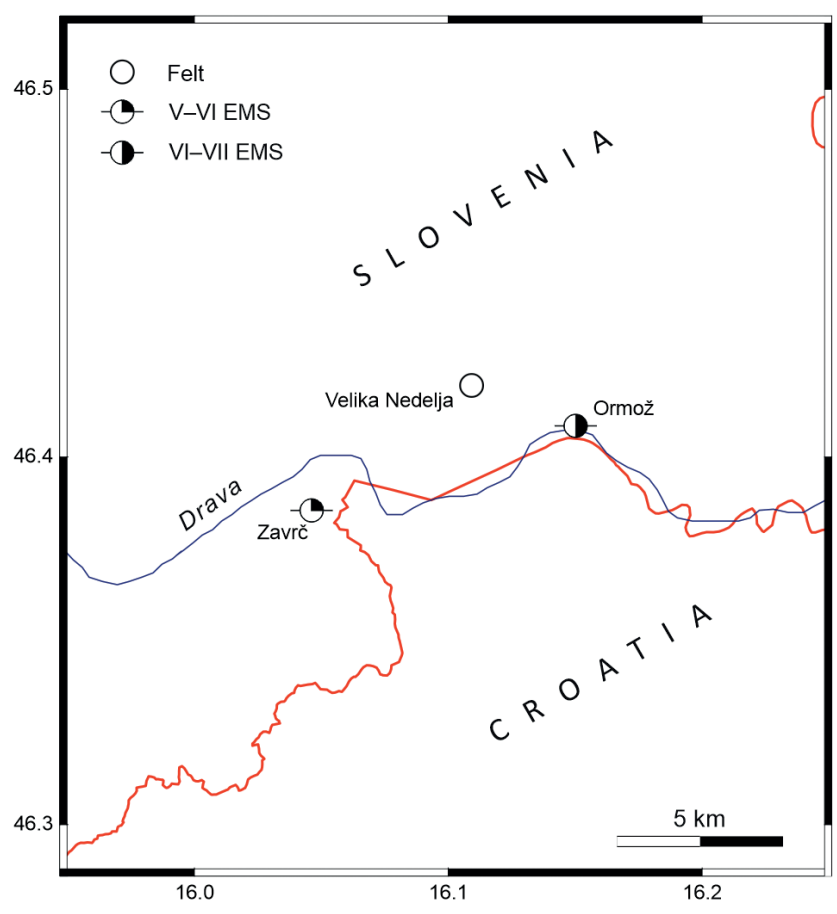

Figure 8. Intensity (EMS) map for the earthquake of 22 March 1839. 
As we only have two intensity points, formal inversion for the location of the macroseismic hypocentre and epicentral intensity is not possible. We therefore put the epicentre to coincide with the location of Ormož where the largest intensity was observed, and accept $I_{0}=I_{\max }=$ VI-VII EMS. Assuming a similar focal depth as for the event of 1838, and the same parameters describing attenuation of intensity, theoretical V-VI isoseismal has a radius of about $10 \mathrm{~km}$, which agrees with the distance of Zavrč (V-VI EMS) from Ormož (VI-VII EMS). We thus propose to use:

$$
\varphi=46.41^{\circ} \mathrm{N} \pm 5 \mathrm{~km}, \lambda=16.15^{\circ} \mathrm{E} \pm 5 \mathrm{~km}, h=5 \pm 5 \mathrm{~km}, I_{0}=6.5 \mathrm{EMS}, \mathrm{M}_{\mathrm{wm}}=4.4
$$

The uncertainties were taken as half of the radius of the isoseismal $\left(I_{0}-1\right)$, and the magnitude is estimated as in section 2.4.

This earthquake was clearly smaller than the one of 1838 described previously. Interestingly, according to the parameters in various catalogues (Tab. 3), with $I_{0}=\mathrm{VI}-\mathrm{VII}^{\circ}$ it was generally considered to be stronger than the event of 31 July 1838 (mostly $I_{0}=\mathrm{VI}^{\circ}$ ), but weaker than the fake one of 26 August 1838 (mostly $I_{0}=\mathrm{VII}^{\circ}$ ) (Tab. 1)! A question may thus be asked if this is an independent event, or should it be regarded as the strongest aftershock of the mainshock of 31 July 1838. On one hand, the interevent time of nearly 8 months is much longer than the duration of the aftershock window $\left(T_{a f t}\right)$ for an earthquake of magnitude 4.8 as proposed, for instance, by Gardner and Knopoff (1974) $\left(T_{\text {aft }}=115\right.$ days $)$ or Uhrhammer (1986) $\left(T_{a f t}=21\right.$ days) (formulas taken from van Stiphout et al., 2012), respectively, which suggests that the two events are unrelated. On the other hand, one could argue that two independent events with reported damage at the same place in less than eight months clearly exceed expected background rates by a large margin, so the temporal window should probably be enlarged and this earthquake should be regarded as an aftershock. We leave this issue, which is important for declustering catalogues to be used in earthquake hazard estimation, open.

\section{Conclusions}

Analyses of all available data on effects of the earthquakes that shook the greater Ormož area at the Slovenian-Croatian border in the 1838 and 1839 revealed that one of them, recorded in a number of regional and global catalogues, is in fact a fake - the earthquake of 26 August 1838 never happened. This error creeped into various reports and studies, and then into many relevant catalogues, following one note on the earthquake of 31 July 1838 in Journal des débats politiques et littéraires (17 September 1838) which seemingly adopted the reporting date from another newspaper and by mistake assigned it to the actual date of the earthquake. In a low-seismicity area as this one, it is important to keep the catalogues as error-free as possible, so this event should by systematically erased 
from the catalogues used to estimate seismicity rates in the neighbourhoods of north-western Croatia, north-eastern Slovenia, and south-western Hungary.

Regarding the earthquake of 31 July 1838, we used important new sources of information (e.g. Maly, 1838; Dajnko, 1840) that have not been consulted in any previous study. This made inversion of macroseismic parameters more robust and reliable. Our estimate of the moment magnitude $\left(\mathrm{M}_{\mathrm{wm}}=4.8\right)$ is mostly higher than the values reported in the available catalogues (Tab. 2). Reliable information on the effects of the smaller event of 22 March 1839 were found for two localities only, so its epicentre was placed to the town of Ormož where the maximum intensity was observed. Its estimated magnitude $\left(\mathrm{M}_{\mathrm{wm}}=4.4\right)$ is close to the median of values found in six consulted catalogues that registered this event (Tab. 4).

The macroseismic epicentre of the 31 July 1838 event lies practically at the junction of the surface traces of the strike-slip Donat fault and the reverse Cakovec fault (LF and ČF in Fig. 1b). Their dips are unknown, but it is reasonable to assume that the Donat fault dips more steeply (nearly vertically) than the Čakovec fault. The macroseismic depth of $5 \pm 5 \mathrm{~km}$ thus favours the Donat fault as the seismogenic source of this event. However, considering the uncertainty of the focal location, as well as of the true nature, position, extent and geometry of the candidate faults, it is not possible to exclude the Čakovec fault - shown by Herak et al. (2020) to be the most likely source for the strong nearby Međimurje earthquake of 1738 - as its source. The situation with the event of 1839 is even vaguer, as the reverse Ljutomer fault (LF in Fig. 1b) must also be considered.

Acknowledgements - We thank two anonymous reviewers for their constructive criticism which helped us improve the manuscript. We also thank Reviewer 2 for pointing us to literature with additional evidence of the Komárom earthquake in July 1838.

\section{References}

Colla, A. (1840): Terremoti sentiti in diversi punti del Globo nell' anno 1838. Giornale astronomico ad uso comune per l'anno MDCCCXL con Appendice di notizie astronomiche, fisiche e meteorologiche, Anno VII, Parma, dalla tipografia Ferrari (in Italian).

Colla, A. (1841): Terremoti sentiti in diversi punti del Globo nell' anno 1839. Giornale astronomico ad uso comune per l'anno MDCCCXLI con Appendice di notizie astronomiche, fisiche e meteorologiche, Anno VIII, Parma, dalla tipografia Ferrari (in Italian).

Dajnko, P. (1840): Župnija Sv. Duha v trgu Središče (Pfarrliche Urkunden zum heiligen Geist bey Polsterau, gesammelt, geordnet und engebunden im Jahre 1840). [Citation after Kovačič, 1910], Zgodovinski arhiv v Ptuju, Ref. code SI_ZAP/0383/012.

Dervarics, K. (1896): Alsó-Lendva története, in: Zalavármegyei évkönyv a millenniumra, edited by Halis, I. and Hoffmann, M., Nagykanizsa, 203-223 (in Hungarian).

Fehér Ipoly, K. (1874): Gyôr megye és város egyetemes leírása, Franklin-társulat nyomdája, Budapest, $674 \mathrm{pp}$ (in Hungarian).

Fodor, L., Bada, G., Csillag, G., Horváth, E., Ruszkiczay-Rüdiger, Z., Palotás, K., Síkhegy, F., Timár, G., Cloetingh, S. and Horváth, F. (2005): An outline of neotectonic structures and morphotecton- 
ics of the western and central Pannonian Basin, Tectonophysics, 410, 15-41, DOI: https://doi. org/10.1016/j.tecto.2005.06.008.

Fodor, L., Csontos, L., Bada, G., Györfi, L. and Benkovics, L. (1999): Tertiary tectonic evolution of the Pannonian Basin system and neighbouring orogens: A new synthesis of palaeostress data, in: The Mediterrannean basins: Tertiary extension within the Alpine Orogen, edited by: Durand, B., L. Jolivet, F. Horváth and M. Séranne, Geological Society, London, Special Publications, 156, 295-334.

Gardner, J. K. and Knopoff, L. (1974): Is the sequence of earthquakes in Southern California, with aftershocks removed, Poissonian?, Bull. Seismol. Soc. Am., 64, 1363-1367.

Gasperini, P., F. Bernardini, G. Valensise, and E. Boschi (1999): Defining seismogenic sources from historical earthquake felt reports, Bull. Seismol. Soc. Am. 89, 94-110.

Gerenčer, L. (2011): Občina Lendava kot učilnica v naravi, Univerza v Mariboru, 136 pp (in Slovenian).

Gomboc, U. (2013): Preobrazba stare panonske hiše v kolesarsko postajališče, Univerza v Mariboru, $69 \mathrm{pp}$ (Diploma thesis, in Slovenian).

Gornjec, J., Hajós, M., Bošnak, J., Lebar, S., Varga, S., Bobovec, F., Ivanec, L., Varga, A., Žižek, F. and Ftičar, Ś. (Eds.) (1981): Zbornik občine Lendava, Čakovec (in Slovenian).

Grünthal, G. (ed.), Musson, R., Schwarz, J. and Stucchi, M. (1998): European Macroseismic Scale 1998. Cahiers du Centre Européen de Géodynamique et de Séismologie 15, European Center for Geodynamics and Seismology, Luxembourg.

Grünthal, G., Wahlström, R. and D. Stromeyer, D. (2009). The unified catalogue of earthquakes in central, northern, and northwestern Europe (CENEC) - updated and expanded to the last Millennium. J. Seismol. 13, 517-541, DOI: https://doi.org/10.1007/s10950-008-9144-9.

Haas, J., Budai, T. (Eds.), Csontos, L., Fodor, L., Konrád Gy. and Koroknai, B. (2014): Geology of the pre-Cenozoic basement of Hungary. Explanatory notes for "Pre-Cenozoic geological map of Hungary" (1:500 000), Geological and Geophysical Institute of Hungary, Budapest, 73 pp.

Herak, D. (1995): Razdioba brzina prostornih valova potresa i seizmičnost šireg područja Dinare. Ph. D. Thesis, University of Zagreb, Zagreb, 145 pp (in Croatian).

Herak, D., Živčić, M., Vrkić, I. and Herak, M. (2020): The Međimurje (Croatia) earthquake of 1738, Seismol. Res. Lett., 91, 1042-1056. DOI: https://doi.org/10.1785/0220190304.

Herak, M. (2020): Conversion between the local magnitude $\left(\mathrm{M}_{\mathrm{L}}\right)$ and the moment magnitude $\left(\mathrm{M}_{\mathrm{w}}\right)$ for earthquakes in the Croatian Earthquake Catalogue, Geofizika, 37, 197-211, DOI: https://doi. org/10.15233/gfz.2020.37.10.

Herak, M., Herak, D. and Markušić, S. (1996): Revision of the earthquake catalogue and seismicity of Croatia, 1908-1992, Terra Nova, 8, 86-94.

Herak, M., Živčić, M., Sović, I., Cecić, I., Dasović, I., Stipčević, J. and Herak, D. (2018): Historical seismicity of the Rijeka region (NW External Dinarides, Croatia) - Part II: The Klana earthquakes of 1870, Seismol. Res. Lett. 89, no. 4, 1524-1536, DOI: https://doi.org/10.1785/0220180064.

Hoernes, R. (1902): Erdbeben und Stosslinien Steiermarks, Mittheilungen der Erdbeben-Commision der Kaiserlichen Akademia der Wissenschaften in Wien, Neue Folge No. VII, 1-115 (in German).

Hoernes, R. (1903): Erdbeben in Steiermark vom Jahre 1750 bis 1870. Mitteilungen des Naturwissenschaftlichen Vereines für Steiermark, 39, 157-296 (in German).

Kaiser, J. F. (1825-1833): Lithographirte Ansichten der Steyermärkischen Städte, Märkte und Schlösser, Graz (in German).

Kárnik, V. (1969): Seismicity of the European Area, part 1, D. Reidel Publishing Company, Dordrecht, $364 \mathrm{pp}$.

Kárnik, V. (1971): Seismicity of the European Area, part 2, D. Reidel Publishing Company, Dordrecht, $218 \mathrm{pp}$.

Kišpatić, M. (1891): Potresi u Hrvatskoj, Rad Jugoslavenske akademije znanosti $i$ umjetnosti, 13, 81-164 (in Croatian). 
Kovačič, F. (1910): Trg Središče, krajepis in zgodovina. Zgodovinsko društvo za Sl. Št., Cirilova tiskarna, Maribor, $630 \mathrm{pp}$ (in Slovenian).

Lendava na spletu (2020): https://lendava-on.net/?s=Potres/ (last accessed 17 January 2021) (in Slovenian).

Mallet, R. (1855): The Facts of Earthquake Phaenomena, Catalogue of Recorded Earthquakes from 1606 B.C. to A.D. 1850, Part III, 1784 A.D. to 1842 A.D., Report of the $24^{\text {th }}$ Meeting of the British Association for the Advancement of Science, Liverpool (1854), John Murray, London, p. 357.

Mallet, R. and Mallet, J. W. (1858): The earthquake catalogue of the British Association with the discussion, curves and maps, etc., Transactions of the British Association for the Advancement of Science, 1852 to 1858, Taylor and Francis, London, p. 278-279.

Mally, G. (1838): Ueber das Erdbeben in Untersteier am 31. Juli 1838. Steiermärkische Zeitschrift, neue folge, I. heft, Vol. 5, Graz, 126-138 (in German).

Meister, X. (1842): Erdbeben und Erdstösse in den Jahren 1839, 1840, 1841. In: Lamont, J. (Ed.), AnnaIen für Meteorologie, Erdmagnetismus und verwandte Gegenstände, 160-163 (in German).

Mioč, P. and Marković, S. (1998): Osnovna geološka karta M 1:100.000, list Čakovec, Institut za geološka istraživanja Zagreb, Inštitut za geologijo, geotehniko in geofiziko, Ljubljana (in Slovenian).

Montandon, F. (1953): Les tremblements de terre destructeurs en Europe: catalogue par territoires séismiques, de l'an 1000 á 1940, l'Union internationale de Secours, Genéve, 195 pp (in French).

Musson, R. M. W. (2009): MEEP 2.0 user guide, British Geol. Surv. Open-File Rept. OR/09/045, 22 pp.

Ožinger, A. (1988): Dajnkova kronika - vir za krajevno zgodovino, 187-201, in: Ormož skozi stoletja, edited by Klasinc, P., III, Skupština občine Ormož, Ormož, 326 pp (in Slovenian).

Peinlich, R. (1880): Chronistische Übersicht der merkwürdigsten Naturereignisse, Landplagen und Culturmomente der Steiermark vom Jahre 1000 bis 1850, Graz (in German).

Perrey, A. (1846): Memoire sur les tremblements de terre, dans le bassin du Danube, Annales des Science Physiques et Naturelles, d'Agricolture et d'Industrie, Société Royale d'Agriculture etc. de Lyon, IX, 333-414 (in French).

Rajh, G., Šket Motnikar, B., Živčić, M., Zupančič, P. and Gosar, A. (2018): Preliminarna analiza potresne aktivnosti po prelomnih potresnih izvorih v Sloveniji. Raziskave s področja geodezije in geofizike 2017: zbornik del / 23. srečanje Slovenskega združenja za geodezijo in geofiziko, Ljubljana, 25 January 2018, 85-102 (in Slovenian).

Rakuša, F. (1886): Domoznanstvo ormoškega okraja, natisnil I. Kordeš, Maribor, 87 pp (in Slovenian).

Réthly, A. (1952): A Kárpátmedencék földrengései. (455-1918): Kiadás: Budapest, Kiadó: Akadémiai Kiadó. Kategóriák: Geológia, 508 pp (in Hungarian).

Ribarič, V. (1982): Seizmičnost Slovenije, katalog potresov (792 n. e.-1981), Publikacije Seizmološkega zavoda SR Slovenije, Serija A, No. 1-1, Ljubljana, 649 pp (in Slovenian).

Sedej, I. (1988/90): Stavbarstvo depriviligiranih družbenih slojev na Slovenskem v devetnajstem stoletju, Slovenski etnograf, 33/34, 310-328. https://www.etno-muzej.si/sl/etnolog/slovenski-etnograf-3334-198890/stavbarstvo-depriviligiranih-druzbenih-slojev-na-slovenskem-v-devetnajstemstoletju (last visited 12 June 2020, in Slovenian).

Shebalin, N. V. (Ed.) (1974): Catalogue of Earthquakes (of the Balkan Region), Part III: Atlas of Isoseismal Maps, UNDP/UNESCO Survey of the Seismicity of the Balkan Region, Skopje, Macedonia, $275 \mathrm{pp}$.

Shebalin, N. V., Kárnik, V. and Hadžievski, D. (Eds.) (1974): Catalogue of Earthquakes I-II, UNDP/ UNESCO Survey of the Seismicity of the Balkan Region, Skopje, Macedonia.

Shebalin, N. V., Leydecker, G., Mokrushina, N. G., Tatevossian, R. E., Erteleva, O. O. and Vassiliev, V. Yu. (1998): Earthquake Catalogue for Central and Southeastern Europe 342 BC-1990 AD, Final Report to Contract ETNU-CT93-0087, Bruxelles.

Šimonka, T. and Bence, L. (2005): Duh Lendave, in; Občina Lendava - Lendva Község - Lendava commune, edited by L. Just, F., Lainšček, F., Murska Sobota, Franc-Franc, 139 pp (in Slovenian) 
Stucchi, M., Rovida, A., Gomez Capera, A. A., Alexandre, P., Camelbeeck, T., Demircioglu, M. B., Gasperini, P., Kouskouna, V., Musson, R. M. W., Radulian, M., Sesetyan, K., Vilanova, S., Baumont, D., Bungum, H., Fäh, D., Lenhardt, W., Makropoulos, K., Martinez Solares, J. M., Scotti, O., Živčić, M., Albini, P., Batllo, J., Papaioannou, C., Tatevossian, R., Locati, M., Meletti, C., Viganò, D., and Giardini, D. (2013): The SHARE European Earthquake Catalogue (SHEEC) 10001899, J. Seismol. 17, 523-544, DOI: https://doi.org/10.1007/s10950-012-9335-2.

Tomljenović, B. (2018): Chapters 3.1-3.3, in: Ivančić, I., Allegretti, I., Dasović, I., Fiket, T., Herak, D., Herak, M., Kuk, K., Markušić, S., Mustać, M., Prevolnik, S., Sović, I., Stipčević, J. and Tomljenović, B. (2018): Rekonstrukcija HE Varaždin, Seizmološki izvještaj, Sveučilište u Zagrebu, Prirodoslovno-matematički fakultet, Geofizički odsjek, Zagreb, 42-58 (in Croatian).

Tomljenović, B. and Csontos, L. (2001): Neogene-Quaternary structures in the border zone between Alps, Dinarides and Pannonian Basin (Hrvatsko zagorje and Karlovac Basins, Croatia), Int. J. Earth Sci. (Geologische Rundschau), 90, 3, 560-578, DOI: https://doi.org/10.1007/s005310000176.

Uhrhammer, R. (1986): Characteristics of Northern and Central California seismicity, Earthquake Notes, 57, 1, 21-37.

van Stiphout, T., Zhuang, J. and Marsan, D. (2012): Seismicity declustering, Community Online Resource for Statistical Seismicity Analysis, last available at http://www.corssa.org. DOI: https// doi.org/10.5078/corssa52382934.

Vogrinčič, B. (2011): Priročnik - tradicionalna gorička hiža, Žitek (Društvo za trajnostni razvoj podeželja), from https://issuu.com/provirus/docs/prirocnik_tgh (in Slovenian).

Zelko, I. (1996): Zgodovina Prekmurja: izbrane razprave in članki. Izbral, uredil in spremno besedo napisal Vilko Novak. Pomurska Založba, Murska Sobota, 333 pp (in Slovenian).

Živčić, M. (1994): Earthquake catalogue, In: Probabilistic Assessment of Seismic Hazard at Krško Nuclear Power Plant, edited by Fajfar, P. and Lapajne, J., Rev. 1, University of Ljubljana, Department of Civil Eng, P. ineering, Ljubljana, Slovenia.

Zsíros, T. (2000): A Kárpát-medence szeizmicitása és földrengésveszélyessége: Magyar földrengéskatalógus (456-1995), Hungarian Academy of Sciences, Institute of Geodesy and Geophysics, Budapest, Hungary, 482 pp (in Hungarian).

Zsíros, T., Monus, P. and Toth, L. (1988): Hungarian earthquake catalog, Budapest, 182 pp.

Newspapers consulted regarding the earthquake of 31 July 1838:

Agramer politische Zeitung, No. 72, 8 September 1838; Allgemeine Zeitung, No. 102, 12 April 1839; Allgemeiner Welt-Kourier zum Humoristen, No. 33, 13 August 1838; Das Pfennig Magazin, No. 310, 9 March 1839; Der Adler, No. 174, 30 August 1838; Der Humorist, No. 129, 13 August 1838; Erdelyi Hirado, 13 September 1838; Gräzer Zeitung, No. 49, 27 March 1839; Gräzer Zeitung, No. 50, 28 March 1839; Hazai és Külföldi Tudósítások, 5 September 1838; Hírnök, No. 70, 30 August 1838; Ilirske narodne novine, No. 72, 11 September 1838; Journal des débats politiques et littéraires, 17 September 1838; Ofner Pester Zeitung, No. 71, 6 September 1838; Pressburger Zeitung, No. 69, 28 August 1838 .

Newspapers consulted regarding the earthquake of 2 August 1838:

Agramer politische Zeitung, No. 72, 8 September 1838; Der Adler, No. 174, 30 August 1838; Erdelyi Hirado, 13 September 1838; Gräzer Zeitung, No. 49, 27 March 1839; Ilirske narodne novine, No. 72, 11 September 1838; Ofner Pester Zeitung, No. 71, 6 September 1838; Pressburger Zeitung, No. 69, 28 August 1838.

Newspapers consulted regarding the earthquake of 22 March 1839:

Allgemeine Zeitung, No. 102, 12 April 1839; Augsburger Postzeitung, No. 102, 12 April 1839; Das Pfennig Magazin, No. 366, 4 April 1840; Der Adler, No. 77, 30 March 1839; Der Adler, No. 78, 1 April 1839; Gräzer Zeitung, No. 49, 27 March 1839; Gräzer Zeitung, No. 50, 28 March 1839; Münchener Tagpost, No. 104, 15 April 1839; Regensburger Zeitung, No. 89, 15 April 1839; Zalai Magyar Élet, 14 June 1941; Agramer politische Zeitung (relevant issues, no data); Ilirske narodne novine (relevant issues, no data); Danica ilirska (relevant issues, no data). 


\title{
SAŽETAK
}

\section{Potresi 1838. i 1839. godine u području Slovenskih gorica i Međimurja}

\author{
Marijan Herak, Davorka Herak, Mladen Živčić i Iva Vrkić
}

Analizom dostupnih podataka iz novinskih izvješća, povijesnih i crkvenih kronika, raznih kronika potresa, putopisnih knjiga, monografija i znastvenih radova o učincima potresa koji su se dogodili u širem području Ormoža na slovensko-hrvatskoj granici 1838. i 1839. godine, ustanovljeno je da je jedan od njih, zabilježen u brojnim regionalnim i globalnim katalozima, zapravo lažnjak. Radi se o navodnom potresu od 26. kolovoza 1838. koji se nikada nije dogodio. Ova se pogreška uvukla u različite biltene i studije, a zatim i u mnoge relevantne kataloge, pa bi taj potres trebalo sustavno brisati iz kataloga koji se koriste za procjenu razine seizmičnosti u područjima sjeverozapadne Hrvatske, sjeveroistočne Slovenije i jugozapadne Mađarske.

Što se tiče potresa 31. srpnja 1838., koristili smo važne nove izvore informacija koji nisu bili korišteni niti u jednoj prethodnoj studiji. To je inverziju makroseizmičkih parametara učinilo robusnijom. Naša procjena makroseizmičke momentne magnitude $\left(\mathrm{M}_{\mathrm{wm}}=4,8\right)$ uglavnom je veća od vrijednosti zabilježenih u dostupnim katalozima. Pouzdane informacije o učincima slabijeg potresa od 22. ožujka 1839. pronađene su samo za dvije lokacije, pa je njegov epicentar smješten u grad Ormož gdje je zabilježen maksimalni intenzitet. Njegova procijenjena momentna magnituda $\left(\mathrm{M}_{\mathrm{wm}}=4,4\right)$ bliska je medijanu vrijednosti pronađenih u šest pregledanih kataloga koji navode ovaj potres. Makroseizmički epicentar potresa iz 1838. godine leži u blizini spoja površinskih tragova Donatskog rasjeda s pomakom po pružanju i reversnog Čakovečkog rasjeda. Na temelju njihove pretpostavljene geometrije i položaja makroseizmičkog hipocentra, dajemo blagu prednost Donatskom rasjedu kao seizmogenom izvoru.

Ključne riječi: potresi 1838. i 1839., lažni potres, Međimurje, Slovenske gorice

Corresponding author's address: Davorka Herak, Department of Geophysics, Faculty of Science, University of Zagreb, Horvatovac 95, HR-10000 Zagreb, Croatia; e-mail: dherak@gfz.pmf.unizg.hr 